НАУКИ О ЗЕМЛЕ

"НАУКА. ИННОВАЦИИ. ТЕХНОЛОГИИ", № 2, 2019

25.00 .30

УДК 551.557 .59

МЕТЕОРОЛОГИЯ, КЛИМАТОЛОГИЯ,

АГРОМЕТЕОРОЛОГИЯ

Смерек Ю.Л., Северо-Кавказский федеральный университет,

Шмигельский В.А. г. Ставрополь, Россия,

smerek@mail.ru, shmigelskiy.92777@mail.ru

\title{
ПРОГНОЗИРОВАНИЕ ТЯЖЕЛЫХ КОНВЕКТИВНЫХ БУРЬ
}

Введение: $\quad$ Одной из наиболее сложных задач, стоящей перед современной синоптической метеорологией, является прогнозирование тяжелых конвективных бурь - смерчей (торнадо). Тяжелые конвективныебури, внетропические ураганы, смерчи, продуктом которых являются грозоградовые процессы, являются опасным природным явлением, приносящем значительный ущерб народному хозяйству, а, иногда, приводящее и к человеческим жертвам.

Материалы и методы:

прогнозирование погодных условий в любом масштабе состоит из двух основных этапов: диагностики состояния атмосферных параметров в настоящее время и прогнозирование их изменений на определенный период времени.

Резупьтаты исследования:

Обсуждение и заключение:

атмосферные параметры, отвечающие завозникновение конвективных бурь (влажность, вертикальный барический градиент и горизонтальная разность температур, и вертикальный сдвиг ветра) требуют тщательного анализа и наблюдения. Такая конвекция часто возникает в форме суперячеек -thunderstorms, характеризуется единым квазипостоянным вращающимся восходящим потоком (известный как мезоциклон), которая сохраняется в течение определенного периода времени. С помощью современных систем наблюдений, таких как вертикально указывающие радары (называемые ветрозащитными устройствами) и системы формирования изображений на спутниках, специалисты обычно могут определить, где условия будут благоприятными для формирования торнадо.

исследования и анализ рассмотренных природных явлений в нашей стране носит, как видно, фрагментарный характер. Изучение и выявление особенностей подобных процессов на территории России требует всестороннего исследования, наблюдений и разработки методов прогноза и предупреждения развития смерчей и ураганов.

Ключевые слова: ураган, смерч, шторм,влажность, разность температур, вертикальный сдвиг ветра 
SmerekYu. L., ShmigelskyV. A.

Materials and Methods:

Results:

Discussion and conclusions:

Keywords:
North-Caucasian Federal University», Stavropol, Russia, smerek@mail.ru, shmigelskiy.9277@mail.ru

\section{Forecasting severe convective storms}

One of the most difficult tasks facing modern synoptic meteorology is the forecasting of heavy convective storms (tornadoes). Heavy convective storms, extratropical hurricanes, tornadoes, whose products are storm-storming processes, are a dangerous natural phenomenon, which brings considerable damage to the national economy, and, sometimes, leads to human casualties.

Weather forecasting at any scale consists of two main stages: diagnostics of the state of atmospheric parameters at present and forecasting their changes for a certain period of time.

the atmospheric parameters responsible for the occurrence of convective storms (humidity, vertical pressure gradient and horizontal temperature difference, and vertical wind shear) require careful analysis and observation. Such convection often arises in the form of super cells -thunderstorms, characterized by a single quasi-permanent rotating ascending current (known as mesocyclone), which persists for a certain period of time. With the help of modern observing systems, such as vertically pointing radars (called windproof devices) and satellite imaging systems, specialists can usually determine where the conditions will be favorable for the formation of a tornado.

research and analysis of the examined natural phenomena in our country is, as you can see, fragmentary. The study and identification of the characteristics of such processes on the territory of Russia requires a comprehensive study, observations and development of methods for forecasting and preventing the development of tornadoes and hurricanes.

hurricane, tornado, storm, humidity, temperature difference, vertical wind shear.

\section{Введение}

В настоящее время усиливается понимание того, что Земля в целом представляет собой чрезвычайно сложную, динамичную и энергонасыщенную систему [1]. В этой связи все более актуальной задачей становится создание обобщенной физической модели атмосферы. Чтобы такая модель отвечала современным требованиям и представлениям, в ней необходимо учитывать термо-, электро- и гидродинамические механизмы атмосферных процессов, влияние солнечно-земных связей, унитарных геополей и 
их локальных возмущений, в том числе, техногенного характера. Имеющихся данных для создания подобной модели еще явно недостаточно, поэтому всестороннее исследование спектра атмосферных явлений остается наиболее интересной и слабоизученной проблемой современной геофизики.

Одной из наиболее сложных задач, стоящей перед современной синоптической метеорологией, является прогнозирование тяжелых конвективных бурь - смерчей (торнадо). Это особенно актуально в средних широтах, где сильные грозы происходят с наибольшей частотой и воздействием. Прогноз усложняется в связи с взаимным влиянием различных атмосферных процессов на развитие смерчей, побочным продуктом которых являются ливни, грозы, град. Эти процессы, некоторые из которых плохо изучены или неадекватно обработаны сетями наблюдений, происходят в широком диапазоне пространственных и временных масштабов. Поэтому исследование развития и эволюция сильных ураганов, смерчей, вероятно, будет оставаться важной задачей для метеорологических исследований и службы прогноза погоды в будущем.

\section{Материалы и методы}

Прогнозирование погодных условий в любом масштабе состоит из двух основных этапов: диагностики состояния атмосферных параметров в настоящее время и прогнозирование их изменений на определенный период времени. Точная диагностика атмосферных параметров имеет важное значение для создания оправдываемого прогноза погоды.

Тяжелые конвективныебури, внетропические ураганы, смерчи, продуктом которых являются грозоградовые процессы, являются опасным природным явлением, приносящем значительный ущерб народному хозяйству, a, иногда, приводящее и к человеческим жертвам. Поэтому диагностическая часть оправдываемого прогноза погоды требует тщательного анализа устойчивости и распределения атмосферных параметров, способствующих возникновениюинтенсивной влажной конвекции. Поскольку условия, связанные с развитием и распространением гроз, встречаются на мезомасштабном уровне и поскольку мезомасштабные процессы, в свою очередь, управляются атмосферными параметрами «синоптического» масштаба, анализ необходимоначинать с обзора указанных параметров. К трем атмосферным параметрам, необходимым для возникновения конвективных бурь относятся: влажность, вертикальный барический градиенти горизонтальная разность температур. Четвертый параметр - вертикальный сдвиг ветра. Такая конвекция часто возникает в форме суперячеек - thunderstorms характеризуется единым квазипостоянным вращающимся восходящим потоком (известный как мезоциклон), которая сохраняется в течение определенного периода времени [1]. 


\section{Результаты исследования и их обсуждение}

Первым шагом в прогнозировании возникновения смерча (торнадо) является выявление регионов, где создаются благоприятные условия для развития сильных гроз. Основными условиями для возникновения таких штормов являются прохладный сухой воздух на средних уровнях в тропосфере, наложенный поверх слоя влажного, условно неустойчивого воздуха вблизи поверхности.

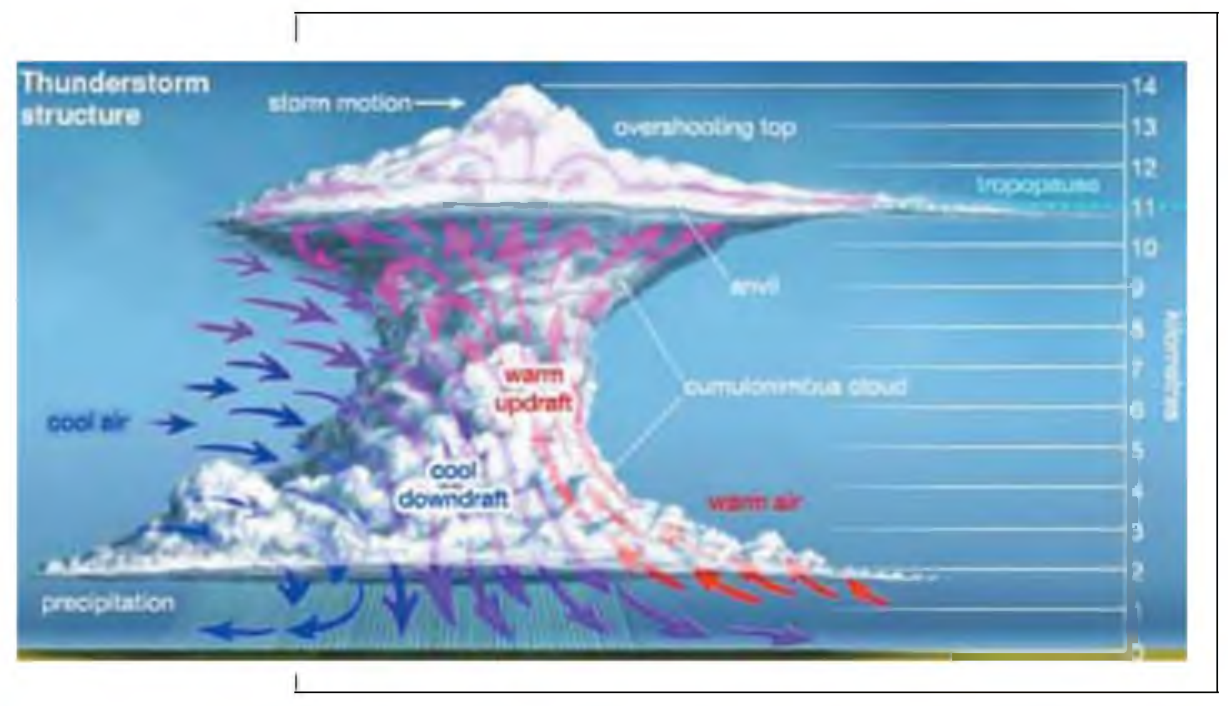

Рис. 1. Структура образования грозовых облаков.

Fig. 1. Structure of formation of thunderstorm clouds.

Когда атмосфера становится нестабильной, возникают мощные восходящие нисходящие потоки (как указано красными и синими стрелками), формируется мощное грозовое облако. Время от времени восходящие потоки достаточно сильны, чтобы распространять верхнюю часть облака на тропопаузу, границу между тропосферой (или самым низким слоем атмосферы) и стратосферой. Условия, обычно приводящие к возникновению грозового облака, происходят по теплой стороне граничной линии или спереди, что отделяет холодный, сухой воздух от теплого влажного воздуха. Степень неустойчивости, присутствующей в атмосфере, аппроксимируется контрастами температуры и влажности на фронтальной границе, разделяющей две воздушные массы. Для шторма, создающего торнадо, должны присутствовать другие факторы. Наиболее важным из них является изменение профиля ветра на низких и средних уровнях, сопровождаюшее постепенным смещениемвектора скорости ветра по часовой стрелке в северном полушарии, против часовой стрелки в южном полушарии с увеличением высоты, 
наряду с сильными ветрами на высоких уровнях. Оба эти фактора изменения скорости ветра необходимы для обеспечения устойчивого вращения в воздухе, которое может в конечном итоге завершиться торнадо. Профиль вихревого ветра может быть обеспечен теми же сильными температурными контрастами, которые влияют на грозу, а высотные ветры могут быть обеспечены струйным потоком, тонкой лентой высокоскоростного воздуха, находящейся в верхней половине тропосферы [2].

Для генерации торнадо диффузный спин должен быть сконцентрирован в небольшой области, поскольку развивающийся вихревой поток проходит через несколько отдельных этапов развития. Первое появление вращения вызвано взаимодействием сильного, стойкого восходящего потока с ветрами, которые дуют и вокруг бури. Вращение усиливается по мере увеличения скорости ветра и направления его с юго-востока на юг, а затем на запад (в северном полушарии) с увеличением высоты через нижнюю половину тропосферы.

Метеорологи в США научаились тщательно контролировать профиль ветра в регионах нестабильности и оценивать, как температура и ветер будут развиваться в течение дня, и в то же время отслеживать движение и интенсивность струйного потока. С помощью современных систем наблюдений, таких как вертикально указывающие радары (называемые ветрозащитными устройствами) и системы формирования изображений на спутниках, которые могут измерять поток водяного пара через атмосферу Земли, специалисты обычно могут определить, где условия будут благоприятными для формирования торнадо, за семь часов вперед. Эта информация передается общественности как часы торнадо. Предупреждение о торнадо выдается, когда торнадо замечено либо визуально, либо на метеорологическом радаре.

Доплеровские радары могут измерять вращение в восходящем потоке и позволяют синоптикам наблюдать за образованием мезоциклона (то есть области вращающегося воздуха в грозу). На доплеровском радаре присутствие хорошо организованного мезоциклона указывается небольшой областью концентрированного сдвига на ветру. С одной стороны мезоциклона вращающиеся ветры текут к радару; а с другой - они уходят. В некоторых случаях может быть обнаружено образование ядра торнадо. Ядро торнадо представляет собой примерно цилиндрическую область с более низким атмосферным давлением, которая ограничена максимальными касательными ветрами (самые быстрые ветры, циркулирующие вокруг центра торнадо). Радиолокационная индикация интенсивного концентрированного вращения называется вихревой сигнатурой торнадо, хотя эта область не всегда развивается в ядро торнадо. Эти улучшения позволили синоптикам увеличить время предупреждения при одновременном снижении ложных тревог.

В абсолютном выражении Соединенные Штаты имеют наибольшее количество смерчей (ежегодно с 1990 года ежегодно регистрируется более 1000 в год). Также в США регистрируются самые сильные торнадо (от 10 до 
20 в год). Торнадо такой интенсивности очень редко встречается за пределами Соединенных Штатов. Канада сообщает о втором по величине количестве торнадо (около 80-100 в год). В Австралии ежегодно регистрируется около 20 торнадо, хотя фактическое число, вероятно, намного выше. Многие бури происходят в необитаемых районах, и поэтому любые торнадо, которые они производят, незадокументированы.Соединенное Королевство имеет наибольшее количество смерчей на каждый размер суши, большинство из них слабы. Ежегодно там сообщается около 33 торнадо.

В России такие природные явления бывают редко - с начала XX века учеными зафиксировано около десяти сильных торнадо.

29 июня 1904 года смерч, зародившийся в Тульской губернии, прошел над восточными окраинами Москвы. Он уничтожил подмосковные деревни Люблино, Карачарово, разрушил постройки в Лефортове, Сокольниках. Были ранены свыше 800 человек.

1 марта 1905 года смерч обрушился на Армавир (Краснодарский край).

2 сентября 1945 года смерч разрушил подмосковные деревни Валентиновку, Хомутово и Оболдино. Он сопровождался крупным градом величиной с куриное яйцо.

17 августа 1951 года через Химкинский район Московской области пронесся смерч, сопровождавшимся ливнем и градом. В августе 1953 года в Ростове (Ярославская область) сильным смерчем были сорваны крыши домов. 2 июня 1974 года разрушительный смерч прошел через Горький (ныне Нижний Новгород). 9 июня 1984 года через Московскую, Калининскую, Ярославскую, Ивановскую и Костромскую области прошли смерчи. Наиболее мощный из них наблюдался в Иванове. В радиусе около 500 метров смерч ломал дома, деревья, столбы, линии электропередач, сносил с рельсов вагоны. Были стерты с лица земли деревни Беляницы и Говядово. По некоторым данным, пострадало 804 человека, погибли 69. 6 июня 1985 года от смерча пострадал восток Ивановской области. 4 июня 2009 года в подмосковном Краснозаводске - в результате смерча были серьезно повреждены около 40 жильх домов, городские коммуникации и припаркованные автомобили. 44 человека обратились в больницы.

В конце XX - начале XXI века прошла череда самых страшных атлантических ураганов: «Эндрю» (1992), «Иван» (2004), «Катрина», «Рита» (2005) и др.

В России ураганов такой силы не бывает, однако в последнее время в ряде регионов участились сильные разрушительные ураганы.

В 1984 году по средней полосе России пронесся ураган большой силы. В ночь с 20 на 21 июня 1998 года на Москву обрушился ураган, в результате которого восемь человек погибли и 157 были ранены.

22 мая 2001 года два человека погибли и 14 человек получили ранения в результате урагана в Пермской области. 21 июня 2001 года ураган, пронес- 
шийся над Кемеровской областью, и град нанесли большой урон двум сельскохозяйственный районам.

8 июля 2001 года ураганный ветер, пронесшийся над Кемеровской областью, оборвал электропровода, в результате чего в Кемерово из-за поражения электротоком погиб мальчик.

26 сентября 2001 года над Сочи в районе Адлера пронесся сильный ураган. Погиб один человек, 25 человек обратились за медицинской помощью. 6 августа 2002 года в Северном районе Новосибирской области в результате урагана, скорость которого превышала 28 метров в секунду, пострадал райцентр Северный и пять прилегающих к нему сел. 8 октября 2003 года на центральную часть России обрушился ураган, от которого пострадали несколько регионов. Самый тяжелый удар пришелся на Рязань - там погибли три человека.

16 июля 2004 года из-за сильного урагана, обрушившегося на Иркутскую область и Усть-Бурятский автономный округ погибло шесть человек пострадало 58 человек.

8-9 января 2005 года над Северной Европой пронесся разрушительный ураган, жертвами которого стали 16 человек. В Санкт-Петербурге 6 января разразился настоящий ливень, сменившийся через сутки сильнейшим ветром.

3 и 4 марта 2006 года ураган обрушился на юг России и северокавказский регион. Шквальный ветер до 35 метров в секунду, сопровождавшийся мокрым снегом, вызвал аварии на высоковольтных ЛЭП и обесточил трансформаторные подстанции на Кубани, в Ставрополье, в Ростовской, Астраханской, Волгоградской областях, в Дагестане и Калмыкии. Последствия урагана оказались столь масштабными, что местные спасатели по примеру американских коллег даже дали ему собственное имя - «Фион». Основной удар стихии пришелся на 7-8 марта

8 марта 2006 года ураган накрыл курорт Сочи. Стихия бушевала в Coчи всего полчаса, а последствия ее разгула устраняли более суток. 8 мая 2006 года в Алтайском крае в результате урагана погибли два человека, еще двое, в том числе ребенок, получили травмы.

11 августа 2006 года ураган пронесся над Читинской областью. Причиной его стал пришедший со стороны Байкала циклон. Во время урагана погиб 15-летний подросток.

18 мая 2007 года мошный ураган ударил по центральным и южным районам Красноярского края. Порывы ветра достигали 30 метров в секунду. 2 июня 2007 года во второй половине дня начался ураган, с порывами ветра до $30 \mathrm{~m} / \mathrm{c}$. Ураган пронесся по ряду территорий Приволжско-Уральского региона; Татарстане, Башкирии, Мордовии и Челябинской области. От разгула стихии было ранено 52 человека, в том числе пять детей. Три человека погибли, один - в Башкортостане, и еще двое - в Челябинской области. 
3 июня 2007 года в Челябинской области во время урагана погибли два человека, еще двое госпитализированы.

11 июня 2007 года ураган обрушился на Амурскую область. Получили травмы и были госпитализированы 5 человек.

17 июня 2007 года ураган прошел в Томской области. Среди сельских территорий наибольший урон нанесен Шегарскому району. В результате урагана по всей области пострадали 11 человек, одна женщина погибла.

8 июля 2007 года в результате урагана, пронесшегося над Татарстаном пострадал 41 населенный пункт [3].

\section{Выводы}

Исследования и анализ рассмотренных природных явлений в нашей стране носит, как видно, фрагментарный характер, несмотря на то, что возникновение и разрушительная сила ураганов и смерчей на территории Российской федерации усиливается в последнее время, и наносит серьезный ущерб сельскому хозяйству, объектам жизнедеятельности населения и приводит к человеческим жертвам. Изучение и выявление особенностей подобных процессов на территории России требует всестороннего исследования, наблюдений и разработки методов прогноза и предупреждения развития смерчей и ураганов.

\section{Библиографический список}

1. Наливкин В.Д. Ураганы, бури и смерчи. Л.: Наука, 1996. 474 с.

2. Ляхов М.Е. Метеорологические условия возникновения и распространения пыльных бурь на Северном Кавказе весной 1960 г. / В сб. Пыльные бури. М.: Гидрометеоиздат,1963.

3. Мамедов Э.С., Павлов Н.И. Тайфуны. Л.: Гидрометеоиздат, 1987. C. 36.

4. Разумов В.В. Притворов А.П., Перекрест В.В., Разумова Н.В., Аджиева А.А. Опасные природные процессы юга европейской части России. Монография. г. Москва. Евразийский институтсоциально-природных // Дизайн. Информация. Картография, 2008.

5. Разумов В.В., Притворов А.П., Перекрест В.В., Разумова Н.В., Аджиева А.А. Опасные природные процессы юга европейской части России. Монография, г. Москва. Евразийский институт социально-природных исследований // Дизайн. Информация. Картография. 2008.

6. Материалы интернациональной конференции Электронного геофизического года. 3-6 июня 2009 г. Россия. Процессы в геологии и физике. М.: Комкнига, 2007. С. 457-470.

7. Бедрицкий А.И., Коршунов А.А., Хандожко Л.А., Шаймарданов М.3. Гидро-метеорологическая безопасность и устойчивое развитие России // Право и безопасность, 2007. № 1-2 (22-23).

8. Волочай М.А., Грицаева М.Н., Закинян РГ. Свободная конвек- 
ция влажного воздуха // Материалы 55-й научно-методической конференции преподавателей и студентов Ставропольского государственного университета «Университетская наука - региону». Ставрополь: СГУ, 2010. С. 16-19.

9. Назаренко А.В. Опасные природные явления // Опасные явления погоды конвективного происхождения, Ч. III: учебно-методическое пособие. Воронеж: Издательско-полиграфический центр ВГУ, 2008.

10. Полянская Н.Е. Условия возникновения конвекции влажного воздуха в атмосфере // Материалы 57 научно-методической конференции преподавателей и студентов Ставропольского государственного университета «Университетская наука - региону». Ставрополь: СГУ, 2012. С. 149-152.

11. Полянская Н.Е. Влияние рельефа на развитие приземной конвекции // Материалы VII Всероссийской научно-практической конференции молодых ученых «Наука и устойчивое развитие». Нальчик, 2012. С. 102-103

\section{References}

1. Nalivkin V.D. Hurricanes, storms and tornadoes. L.: Science, 1996. $474 \mathrm{p}$.

2. Lyakhov M.E. Meteorological conditions for the origin and spread of dust storms in the North Caucasus in the spring of 1960 / In the collection. Dust storms. Moscow: Gidrometeoizdat, 1963.

3. Mamedov E.S., Pavlov N.I., Typhoons. L.: Gidrometeoizdat, 1987. P. 36

4. Razumov V.V., Pritvorov A.P., Perekrest V.V., Razumova N.V., Adzhieva A.A. Dangerous natural processes in the south of the European part of Russia. Monograph. Moscow. Eurasian Institute of Social and Natural Research // Design. Information. Cartography, 2008.

5. Razumov V.V., Pritvorov A.P., Perekrest V.V., Razumova N.V., Adzhieva A.A. Dangerous natural processes in the south of the European part of Russia. Monograph. Moscow. Eurasian Institute of Social and Natural Research // Design. Information. Cartography, 2008.

6. Materials of the International Conference of the Electronic Geophysical Year. June 3-6, 2009, Russia. Processes in geology and physics. M. Komkniga, 2007. S. 457-470.

7. Bedritsky A.I., Korshunov A.A., Khandozhko L.A., Shaymardanov M.Z. Hydrometeorological safety and sustainable development of Russia // Law and Security, 2007. № 1-2 (22-23).

8. Volochay M.A., Gritsaeva M.N., Zakinyan R.G. Free convection of moist air // Proceedings of the 55th scientific and methodological conference of teachers and students of the Stavropol State University "University Science-Region". Stavropol: SSU, 2010. S. 16-19.

9. Nazarenko A.V. Dangerous natural phenomena // Dangerous weather phenomena of convective origin, $\mathrm{Ch}$. III: educational-me- 
thodical manual. Voronezh: Publishing and Polygraphic Center of VSU, 2008.

10. Polyanskaya N.E. Conditions for the emergence of convection of moist air in the atmosphere // Proceedings of the 57th scientificmethodical conference of teachers and students of the Stavropol State University «University Science-Region». Stavropol: SSU, 2012. P. 149-152.

11. Polyanskaya N.E. Influence of the relief on the development of surface convection // Proceedings of the VI All-Russian Scientific and Practical Conference of Young Scientists "Science and Sustainable Development". Nalchik, 2012. P. 102-103

Рукопись поступила в редакцию 03.03.2019 г. Принята к публикации 01.06.2019 г.

\section{6 авторах}

Смерек Юлия Леонтьевна, кандидат фризико-математических наук, доцент кафедры общей и теоретической фризики СевероКавказского федерального университета

Телефон 8(918)758-71-29

E-mail: smerek@mail.ru

Scopus ID: 6503952686

ResearcherlD is: Q-5159-2018

Шимгельский Владимир Андреевич, аспирант кафедры общей и теоретической фризики Северо-Кавказского федерального униваерситета

Телефон 8(906) 470-57-25

E-mail: shmigelskiy.92777@mail.ru

ResearcherID is: Q-3869-2018

\section{About the authors}

Smerek Yulia Leontevna, Candidate of Physical and Mathematical Sciences, Associate Professor, Chair of General and Theoretical Physics, North Caucasus Federal University

Phone 8 (918) 758-71-29

E-mail: smerek@mail.ru

Scopus ID: 6503952686

ResearcherlD is: Q-5159-2018

Shimelsky Vladimir Andreevich, post-graduate student of the Department of General and Theoretical Physics of the North Caucasus Federal University

Phone 8 (906) 470-57-25

E-mail: shmigelskiy.92777@mail.ru

ResearcherIDis: Q-3869-2018 